\title{
WestVirginiaUniversity
} THE RESEARCH REPOSITORY @ WVU

Graduate Theses, Dissertations, and Problem Reports

2017

\section{High Touch}

\author{
Andrew Kellner
}

Follow this and additional works at: https://researchrepository.wvu.edu/etd

\section{Recommended Citation}

Kellner, Andrew, "High Touch" (2017). Graduate Theses, Dissertations, and Problem Reports. 5957. https://researchrepository.wvu.edu/etd/5957

This Thesis is protected by copyright and/or related rights. It has been brought to you by the The Research Repository @ WVU with permission from the rights-holder(s). You are free to use this Thesis in any way that is permitted by the copyright and related rights legislation that applies to your use. For other uses you must obtain permission from the rights-holder(s) directly, unless additional rights are indicated by a Creative Commons license in the record and/ or on the work itself. This Thesis has been accepted for inclusion in WVU Graduate Theses, Dissertations, and Problem Reports collection by an authorized administrator of The Research Repository @ WVU. For more information, please contact researchrepository@mail.wvu.edu. 


\title{
High Touch
}

\author{
Andrew Kellner
}

Thesis submitted

To the College of Creative Arts

At West Virginia University

\begin{abstract}
In partial fulfillment of the requirements for the degree of
Master of Fine Arts in

Ceramics
\end{abstract}

\author{
Shoji Satake, M.F.A., Chair \\ Jennifer Allen, M.F.A \\ Dylan Collins, M.F.A \\ Alison Helm, M.F.A \\ Robert Moore, M.F.A \\ School of Art and Design
Morgantown, West Virginia
2017

Keywords: Ceramics, Pottery, Clay, Earthenware, Fine Art, Utilitarian, Process, Fine Craft, Vessel, Utility, Functional Art, Slipware, Salt-firing, Domestic Pottery, Contemporary Ceramics, Ware, PB\&J

Copyright 2017 Andrew Kellner 


\author{
Abstract \\ High Touch \\ Andrew Kellner
}

This written thesis is the supporting documentation for High Touch, my Master of Fine Arts thesis exhibition. The exhibition seeks to define my personal expression of beauty through domestic pottery that seeks to both elevate and celebrate mundane life experiences.

The research underpinning my thesis explores the connections between object and user. The use of pottery, particularly in the home, has the ability to breed familiarity, consolation, comfort and security. It is only when pots are put into service within the household that an affinity for the object is achieved and its unique character is revealed. These moments cannot be codified or appropriated because they are fleeting, immediate and sustained only through the everydayness of daily routine.

Documented through contemporary and historical influences, material/processes, and narratives of utility, my pottery's intrinsic value and meaning in the $21^{\text {st }}$ century is identified.

Handmade pots have their own story. They contain a kind of individuality that imbibes them with a sense of joy or humor, grit or sadness. They are more than mere objects because they represent a part of the individuals who made them and as such their inherent individuality has the ability to stimulate new interactions with the people who use them. Through daily activities, pottery and craft objects brighten the mundane. 


\section{Acknowledgements}

I would like to express my sincere gratitude to all of my committee members, professors and my fellow graduate students of West Virginia University; for providing the necessary resources and encouragement to explore and find my voice. A very special thanks goes out to Shoji, Boomer, Jen and Kelly for always being around when I needed advice.

I would also like to especially thank my wife Victoria Kellner, for the support and patience during my M.F.A degree. 


\section{Table Of Contents}

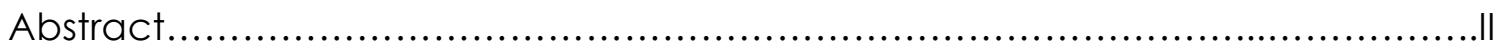

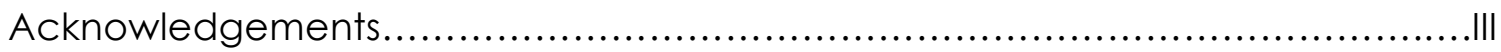

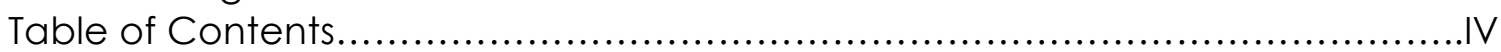

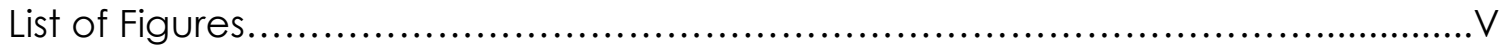

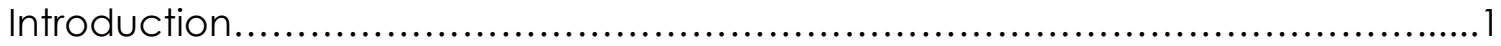

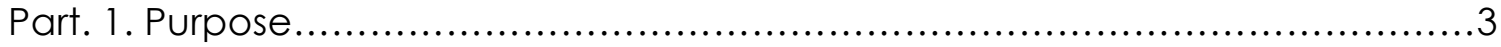

Part. 2. Process / Materials................................................................ 5

Part. 3. In Use .................................................................................

Part. 4. Influences.....................................................................

Part. 5. High Touch.................................................................. 11

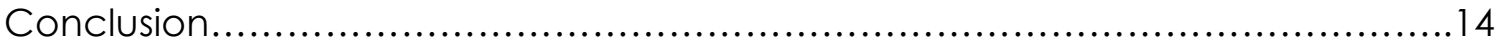

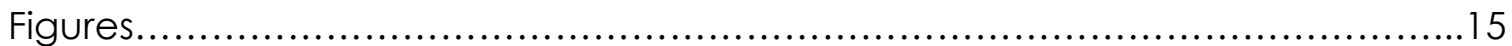

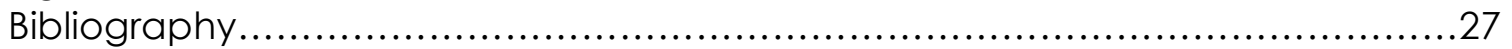

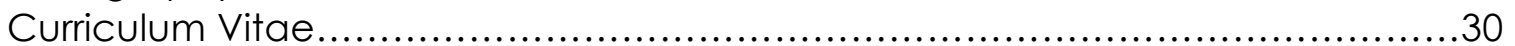


List of Figures

Figure 1. Andrew Kellner, Stacked Dishes......................................... 15

Figure 2. Japan, incipient Jōmon /final Jōmon, 14000-1500 B.C.E....................15

Figure 3. Andrew Kellner, Trimming Detail of Jug..................................... 16

Figure 4. Peter Voulkos, Teabowl (Detail), n.d........................................ 16

Figure 5. Andrew Kellner, Detail of process marks..................................... 17

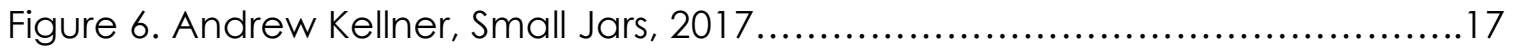

Figure 7. Watershed "Wet-struck" Brick, n.d............................................. 18

Figure 8. Linda Christianson, Cooking Oil Can, 2017.....................................18

Figure 9. Steven Colby, Lidded Jar, 2011 .................................................. 19

Figure 10. Jean Nichols-Gerrad, Small Lidded Jar, 2016.................................19

Figure 11. Dylan Bowen, Soft Cut Form, n.d...........................................20

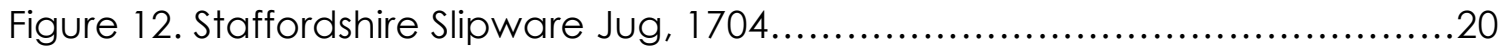

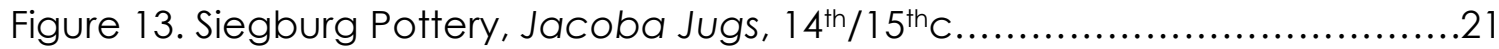

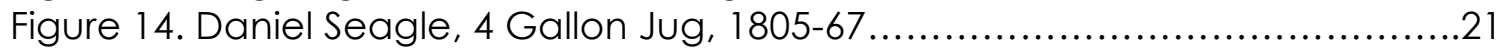

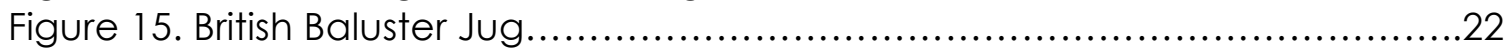

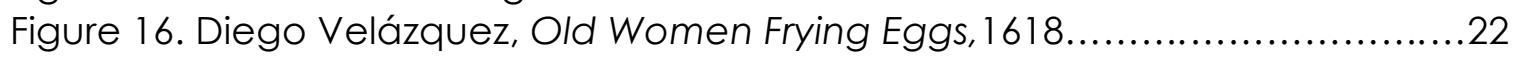

Figure 17. Diego Velázquez, Waterseller of Seville, 1618-1622........................23

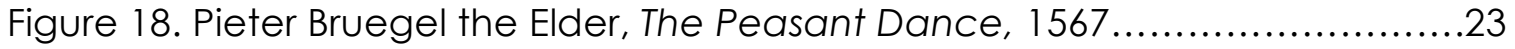

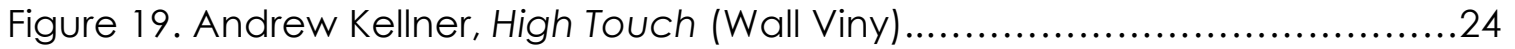

Figure 20. Andrew Kellner, High Touch (Installation View) .............................24

Figure 21. Andrew Kellner, Storage Jar, 2017............................................25

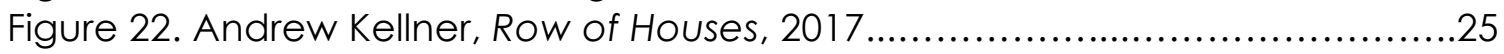

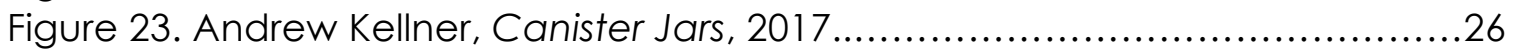

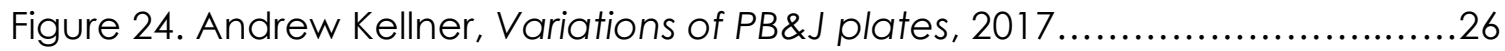


Introduction

My pottery aims to elevate and celebrate everyday life experiences. I want my work to act as an invitation to the user to be a more active participant in the daily rituals that revolve around the domestic setting. Ceramics is an excellent conduit for purposeful touching. It engages the user in texture, hardness, temperature, and weight. Interacting with these physical cues creates an experiential affinity with the immediate physical environment. It allows the user to make connections with the object through memories or past experiences. These connections breed familiarity, consolation, and comfort, even security. These moments cannot be codified or appropriated. They are fleeting, immediate and sustained only through the everydayness of daily routine.

Fine craft, for me, is work done for its own sake while honoring the traditional hand-skills/methods of the past. It excites, making the absurd struggle of life enjoyable by finding simple, joyful moments in small and innocuous ways. The texture of a familiar plate, for example. In this way, I believe pottery has an innate power to create brief instances of small pleasure in the mundane moments of the everyday.

The act of eating from, washing and storing dishes contributes to a series of communicative moments between users and the maker (Fig.1). The necessity and repetition of daily patterns present opportunities to remind us of our relationship with things, as well as our connection to the outside world. Utilitarian pottery brings a kind of individual beauty and art into our homes. This is most true when a functional object is put into service. The potential for the handmade, as Paul Mathieu explains, "...play(s) a seminal role in human experiences, a role that cannot be filled or effectively replaced by other objects." "Ceramics may be mistaken as simplistic and inconsequential to some because of its familiar usage in the home, however, pottery is emblematic of more than a food vessel. It is a visual representation of time, memory, and history, which actively adds to and transports each of these experiences through use. For example, a simple dinner plate taken from the cupboard, filled with food, and placed on the

1 Mathieu. The Art of the Future: 14 Essays of Ceramics. Ch.8 P.13. 2008 (www.paulmathieu.ca/). 
dinner table becomes a carrier not just for the food, but also for the occasion itself. The user imbues the vessel with meaning because it is unique, and this uniqueness adds a tone to the meal and the company who use it. The users imprint these memories into the dishes. They become symbolic representations of family occasions. Touching a specific pot may suddenly bring to mind significant occasions by relying on the muscle memory associated with the feel of the graininess of the dish itself or the smoothness of the glaze. It may even bring to mind the smell of the food and the conversation that flowed around it. The experience of ceramics is slow. It develops over a long period of time of low intensity. ${ }^{2}$ I rely on the subtle, almost dismissible impressions in clay to lead to a lasting impression. In this way the power of pottery evolves slowly over time as it exists our homes. It is not a part of a throwaway culture but is archival, holding/containing information on both past and present.

This paper documents my research into aesthetic formal decisions through my making process. Each section will examine different parts of my investigation into domestic ceramics from a variety of contexts: historical connection, material process, beauty and influences.

\footnotetext{
2 Mathieu. The Art of the Future: 14 Essays of Ceramics. P.6.
} 


\section{Part 1. Purpose}

The purpose of my craft in the 21-st century is to contribute a sense of "groundedness" within the family setting. Pottery, like many other crafts, enters our consciousness primarily through physical interaction. With time and regular employment, users achieve a deeper and more layered appreciation for ceramics. Tupperware ${ }^{\circledR}$ and disposable paper plates do an adequate job of serving sustenance, however, the encounter with these objects is ordinary and boring, not elevated, "... [handmade pottery] doesn't compete with food but complements it, actively participating in the enjoyment of the occasion. They also stand as talismans of hope amid the disturbing wasteland of fast food and disposable packaging."3 Through its utility, pottery provides an intersection between art, individual beauty, and pleasure in the home. All of our senses are activated when we engage a craft object. For example, you might lick your plate clean after a meal and enjoy the grittiness of the plate, or listen to the particular clamor as dishes are stacked in the cupboard. These activated senses of sight, touch, sound and taste add to the beauty of the object.

It is ultimately through use that we orchestrate an experience. Sometimes it is only through repeated use that we can we start to understand the value of pots in the home. There is a kind of essential, soulful nourishment gained from a well-crafted object that has found its purpose in repeated usage. As Mark Hewitt explains, "by far and away its most important function [pottery's], underlying all the historical evolutions of separate traditions has been to contain food and drink...the constant relationship with food has probably played the most vital part in endowing pots with their special symbolic qualities... This intimate connection with a potent aspect of daily life and experiences is what gives ceramics its particular aesthetic interest." ${ }^{4}$ Ceramic dishes are intended to give pleasure in use. They only reach their full potential through active participation.

This participation can be seen perfectly as far back to the Jomon culture in Japan. Highly decorated conical containers were used that evolved from simple to ornate over a span of 14,000 years. These containers had one purpose:

3 Hewit, Sweezy. Potters Eye Art and Tradition in North Carolina Pottery, 115.

${ }_{4}^{4}$ Rawson, Ceramics (Philadelphia: University of Pennsylvania Press, 1984), 3. 
the making of chestnut stew (Fig.2). A particular dish was created and refined simply for this stew and it was this intersection between food, dish, and culture that resulted in some of the most ornate and beautiful cooking pots of the time.

Using traditional methods, I am able to immediately contribute to, and participate with, pottery's fifteen thousand years of history and tradition. This connection to history is important so I can create a meaningful dialog between the past and the present. As Mark Hewitt states, "Potters and ceramic artists use ceramic history and particular traditions to inform their work, and those traditions inspire rather than discourage innovation." ${ }^{5}$ As craftsmen we are able to use this shared history as a guide in our individual search for beauty, value, and self.

5 Hewit, Sweezy. Potters Eye Art and Tradition in North Carolina Pottery. (Chapel Hill: University of North Carolina Press, 2005), 3. 
Part 2. Process / Materials

Aside from formal decisions, I am interested in exposing the textures and rich surfaces of salt-fired earthenware. My aim is to create more opportunities, and intimate connections with the people that use my work. I use spontaneous, rough, hefty and subdued processes, similar to how Daniel Rhodes reflects upon Japanese Tamba ware, ..."their very flaws seem to put us closer to the ceramic process and to lend a warmth and human quality. What [Tamba pottery] miss in sophistication and suavity they make up for in rugged strength and vividness." 6 My throwing is quick and energetic, and after I'm done throwing, I trim back into the clay, which creates serendipitous opportunities. As I cut away the lower portions, like a hot knife through butter, the slick smooth surface of the thrown form disappears to reveal the gritty grog and the trail lines within the clay (Fig.3). The contrasting textures of slick and rough provide what I see as an extra layer of information to the user. My aim is to make pots that deliberately stray from the conventions of perfection. Sōetsu Yanagi says it best, "The precise and perfect carries no overtones, admits of no freedom; the perfect is static and regulated, cold and hard."7 (fig.4). My ceramic ware is warm and inviting, similar to a Voulkus Teabowl. I try to emulate a child's naivety and freedom to create a sense of warmth within my work.

The resulting decoration acts as a record, both of the action as well as the process. The poured slips add yet another layer of interest over the trimming marks, which reveal the hidden granules of grog. When I sit down at the wheel, I make small familial batches of pots. In this way, I emphasize and adapt the nature of the potter's wheel so that I can evolve the work as I make it. I am not tied to specific weights and instead measure the elegance in the shape of a belly, or the energy in a mark as it travels through the form. I mindfully and sparingly touch the clay, which allows me to better expose and highlight the raw beauty of the material throughout the process. Through each of the layers I leave behind energetic and playful impressions of my hand as "traces" of my action (Fig.5), exhibiting evidence of my presence as well as a kind of cheeky

\footnotetext{
6 Rhodes, Tamba Pottery:The timeless Art of a Japanese Village. (Tokyo: Kodansha Interantional, 1970), 62.

7 Yanagi, Sōetsu. The Unknown Craftsman A Japanese Insight into Beauty. (USA: Kondasha, 2013), 120
} 
reminder that real hands made these dishes. "In craft, a person always stands, like a shadow, in close proximity to the thing itself." 8 What I make acts as a communicator of experiences that I wish to share with the world. I believe I am also offering an intimate connection or "groundedness" with the world when, for example, the user selects my cup for their first cup of coffee in the morning or their final cup of water before bed.

I play with, and revel in, what I see as this quick and pragmatic method of embellishment in forms. From handles and cut away sections, and undulations of the form, these actions contribute (Fig.6) a sense of playfulness to the pots. I am communicating, and inviting the viewer to reach out and interact with the dishes.

The clay I use echoes the grainy, rough quality of early "wet struck" bricks (Fig.7). Bricks convey sentiments of weight, home, and safety, which are all concepts that I incorporate into the work. "... [Pottery is] appeal[ing] to the senses on several different levels; it is a labyrinth of aesthetic values. Of course on a rudimentary level, it is simply something to drink out of, a useful functional object - it works, it does its job. But by picking it up you have color in your hand, the electricity of texture against your lips, and the muscular instruction of balance in your mind."

I like to think that my pieces activate the senses and begin a kind of conversation with the user. For example, the shimmering rich satin surface that is produced by the salt firing calls out to the user with its satin matte texture. The weight of the lid is heavy, forcing the user to be mindful of their actions.

My goal is to give up any pretenses I have by humbling my desires, vanities, and expectations to the making itself. I aim to relinquish control to the material and process by employing intuition and chance into the work. There can be a thickness in slip application, or a change in the amount of salt, or reduction used in a firing. These factors change the work, allowing me to stay focused through the entire process. I see myself as a conduit between two earth elements, the clay and the fire that transforms it. My throwing involves energetic

\footnotetext{
${ }^{8}$ Metcalf, Bruce. "The Hand: At the Heart of Craft." American Craft 60, no. 4 (August/September 2000).

9 Hewit, Sweezy. Potters Eye Art and Tradition in North Carolina Pottery. (Chapel Hill: University of North Carolina Press, 2005), 49
} 
pulls to incorporate a sense of unpredictability. This allows me to open myself up and feel vulnerable. My aim is to relinquish absolute control, to stop thinking about how I am touching the clay, and intuitively react with the material, allowing material, process, and artisan to play equal roles in establishing a sense of beauty.

I am directed by a variety of things in this process; a subtle sense of volume in the belly and heft of the clay for example, or a soft undulating lip that almost defines the transition between interior and exterior and provides a place to attach a handle, if necessary. Sometimes this can be a stretched throwing line that draws the eye through the form and requires only the subtlest encouragement. What intrigues me, what keeps me coming back to the potter's wheel, is the need to improve and make better.

Once the pots are out of the kiln and finished, my attachment to the object is lost. It is the process of the making that draws me in. I glean what I can through every stage of the process so that I can improve my craft when it comes time to start the cycle over again. This ideology of making, of wanting to improve from the previous batch, is why I am a maker, why I am a $21^{\text {st }}$ century potter. People don't need my dishes to survive. But with them they can grow, be inspired, and be comforted. 
Part 3. In Use

Once the ware is completed, my hope is that they introduce a sense of individualized beauty and craftsmanship into the home. My wish is that my pots have the ability to add to and even improve the quality of life within the household by embodying a sense of playfulness, individuality, and craftsmanship. My desire is to arrange an experience of the senses, and to invite meaning, setting the stage for the user to accumulate memories and attachments through familiarity, touch, and utility. Take for instance a bowl reserved only for ice cream. Now imagine a bowl used only for "sad" ice cream moments. At these times the bowl itself is transported into a vehicle of restoration, a quiet moment of personal reflection and healing. Now consider a pitcher for homemade iced-tea during warm months, "The object becomes a medium for this gesture of aid and comfort. The pot, the garment, the necklace: each becomes an extension of the maker, and a vehicle for the makers sympathy." 10 The pitcher becomes symbolic of the idea of refreshment and relaxation. It becomes a luxury.

The point here is that it is only when the ceramics are put into service within the household that an affinity for the object and its unique character is revealed. Perhaps it is that the cookie jar that has wiggly coils flying off the surface that begs to be hugged, or grabbed by a child teetering on a stool and reaching for a stolen treat. Later in life memories will have been forged of the texture, color, smell, and warmth of that jar, and the feel of the funny coils. In this way I believe a link is created with the object through the tactual response, elevating it from a visual pleasure to a tangible pleasure. These kinds of attachments and experiences are important to our emotional growth and to our personal development. Without beauty and an appreciation for the handmade objects we have in our lives, we might as well be robots. In use, pottery creates a communication among the users, facilitating meaning in the mundane everyday.

10 Metcalf, Bruce. "Embodied Sympathy." Metalsmith 22, no.3 (Summer 2002) 


\section{Part 4. Influences}

I draw inspiration from contemporary ceramicists that handle clay confidently and daringly transform it beyond the conventional, such as Linda Christianson, Jean Nicholas-Gerard, Dylan Bowen and Steven Colby. These ceramicists all share an almost poetic elegance in their respective styles, as well as a love for clay and its rootedness in the domestic setting.

Christianson and Colby both have a reverence for the tradition of pottery, though they come to it in different ways. Christianson's work is slow and paired down to the bare elements: spout, body, and cap as seen in her ewer. (Fig.8) The elegant throwing marks show off the methodical throwing and casualness to the making. The craft exemplifies a lively, visual, and volumetric form that is accentuated from the wood-salt atmosphere. The long reach of the fire licks around, highlighting the placement in the kiln. That arrangement creates rich and subdued areas on each piece.

Colby embeds emotion and gesture, adding and removing layers of slip to distress the surface. His intention is to express comfort and beauty in the well worn (Fig.9). Even after the firing, Colby's pots retain the vigor of the wet and freshly thrown clay. Colby and Christianson intention is functional work. As Simon Levin puts it, "...in the home, rather than an artistic institution... I feel we potters should exploit. A cup is one of the first things we hold in the morning, and often one of the last things we touch at night." 11

Contemporary slipware potters like Jean Nicholas-Gerard (Fig.10) and Dylan Bowen (Fig. 1 1) both explore ideas of domestic ware through quick, gestural and animated forms with decoration. They draw influences from the casual confidence of $17^{\text {th }}$ century British slipware (Fig.12) and $15^{\text {th }}$ century German Siegburg ceramics (fig.13).

My own work revolves around similar ideas to Christianson, Colby, Nicholas-Gerard, and Bowen. I am attracted to the sensory pleasure of making, and the continual negotiation of internal / external volume, form, and surface, wanting these objects to live in the home, to act as an element of pleasure and

"Levin, Simon. Artist Statement. Simon Levin. Accessed October 16, 2016. http://simonlevin.com. 
functionality within the routines of daily life. "In the past few decades the acceleration of this process of the dissolving of connections has become so rapid that we perceive it and have become frightened by the absence of meaningful links between ourselves and the things we live among."12 The aim is to try and reverse this trend, one pot at a time, for the work to enter the home in the hope that they provide a visual as well as a tactile connection, a connectedness between user, maker, and the objects in their lives.

I look to the pottery of our shared past and romanticize the time in which they were made; I have this idealized idyllic/fetishization of their process which I look upon for inspiration. Early Jug-Town, North Carolina (fig.14) for example, is of particular interest for its simplicity of form, power in utility and a necessity for survival. The Medieval English Baluster jug (fig.15) stand outs with its quick energetic vertical stripes that exaggerate the belly, neck of the pot and amplifies the flowing liquid as it's poured.

Researching historical ceramics only becomes alive when viewed through paintings. Only then can I visualize how and where these pots really became alive. Painters such as Diego Velázquez with "Old Women Frying Eggs" (fig.16), "Waterseller of Seville" (fig.17) or Pieter Bruegel "The Peasant Dance" (fig.18) all depict pots in action, their innate beauty in full swing.

12 Needleman, The Work of Craft. (New York: Kondasha Intl, 1993), 47 


\section{Part 5. High Touch}

Throughout my three years in graduate school my focus was directed toward becoming more comfortable with my craft, to really enjoy my own work. My role as a maker is to make good pots that I want to use, and that is what I presented in my exhibition High Touch (Fig.19) (Fig.20).

Setting up the show was a moment when things really clicked; when I saw my pots in a new light. Each piece on its individual lit pedestal cemented the fact that what I had made was a beautiful object. What I do is important, not just for me as a maker, but as something important to share with others. It was at that point that I understood the critical role of seeing domestic pottery in a gallery setting, to see the work as beautiful, standalone objects as compelling as any other piece of contemporary art.

Pots are more than mere vehicles for food; they are visual representations of time, memory, and history. All three of these sentiments are actively added to and transported with the experiences of use. It was for this reason that I titled the show High Touch, referring specifically to the weight and feel of the pots that add to the small moments of daily experience in life. Take for example my "Storage Jars" (Fig.21). When the user runs their hands over the jars they will feel the undulations created from my fingers poking the pot from the inside and creating protuberances. History can also be seen in this jar where I have chosen to pay homage to the brick makers that build our houses. The lower third of the jar is cut into in order to reveal the rough groggy interior of the clay, similar to the texture and look of early "Wet Struck" bricks. Only through touch can one feel and experience the heft of the knob. To me these pots are not fully completed until they are touched and used by people.

"Row of Stacked Houses" (Fig.22) and "Series of Canister Jars" (Fig.23) are placed on opposite sides of the gallery. One speaks of a small but pivotal moment in my life. The other refers to where I am from, in a manner of speaking. "Row of Stacked Houses," individually, is a three-tiered container. I installed ten of these containers in a row to resemble the tightly packed streets of Toronto, Canada, where I grew up. 
"Series of Canister Jars" refers to a time when I apprenticed in Northern Saskatchewan, Canada. I loved the isolation, the forever fields that surrounded the town and the grain silos that popped up in the middle of what seemed to be nowhere, and which were very nearly the only visual markers around me. I have always wanted to return to the remoteness of the country, or at least to my idealized city boy notions of the simplicity of country living. These two areas in Canada were critical to the shaping of who I am as a person and as a maker of domestic ceramics.

My graduate school education was a period of time that gave me permission to be selfish. As a potter, I make pots so that others may use and enjoy them with family and friends, as well as to share my idea of beauty with others. "Variations of PB\&J Plates" (Fig.24) was something that I created entirely for myself. It refers to my primary meal throughout school, peanut butter and jam sandwiches. I wanted to make a dish that was specific to this food, a food that I had spent the last two and half years subconsciously researching through nearly every meal.

The plates have a textured surface that works to slightly raise the level of the sandwich up from the plate, thus making it easier to grab with my hand. The rim of the plate has a low profile and is vertical, so the sandwich will not easily fall off the plate when walking or moving around. The plate has a wide flat bottom so it can rest just as easily on my lap as on a table. The physical research, the intuitive understanding and time spent eating, was critical in the development of the dishes. Had I not been in this exact situation over the past two years these plates may not have come to fruition. The plates were created because of the concentrated time spent eating two to three PB\&J sandwiches a day over the past two years.

The surface treatment of the pots in the show, the black and white slip decoration, is purposeful, especially in the variations. Fluctuating from rich dark blue to creamy white satin surfaces, these stemmed from shifts in the firing or the application thickness of the slips themselves. I wanted to show that chance and intuitive learning play an important role in my work. These particular colors occurred by changes in firing patterns, such as change in climate, stacking and 
amount of salt introduced. These chance factors are inherent to my making process. The slip itself helps to show off all the little imperfections, such as pooling in cut lines, fingerprints that shout out for attention, the slip pools, and the breaks on edges that cascade over the bellies to show off the swelling forms. I used a color pallet of simple black and white tones so that my pots could disappear in private and personal activities. This paired down color scheme accentuates the simplicity of the pots and their ruggedness, letting particular moments take center stage. This is important; pottery only becomes active when we commit them into service. 
Conclusion

The use of pottery and craft objects in my own daily activities serve to brighten the mundane moments. I believe that a meaningful life can be found within the bonds of friends and family, around the dinner or coffee table or in the backyard. The only thing scarier than not knowing why we exist is the thought of not having anyone to share existence with. David Pye talks about the "workmanship of Risk."13 To me, risk is present when I make something with my hands. I don't know how anyone is going to react to the finished piece. I also don't know how the finished pot will turn out. This is like life itself. In life, relationships are messy and contain unpredictability. Life is about feelings, emotions, and how people connect with one another. Life is about how we tell ourselves our stories. In the same way, handmade ceramics have their own story. They contain a kind of individuality that imbues them with a sense of joy or humor, grit, or sadness. They are more than mere dishes because they are as individual as the people who make them and as such, they stimulate interactions. Finally, they are imbued with their own sense of meaning and intimacy simply by virtue of being part of something larger, specifically, a life. My time in graduate school has provided me with a rediscovery of myself as a potter; I am demonstrating an investigation into my idea of beauty, as well as a reflection of myself directly: coarse and determined. The end result of my thesis exhibition is meant to bring beauty into the everyday domestic setting.

13 Pye, The Nature and Art of Workmanship. (London: Herbert Press. 1995) 
Figures

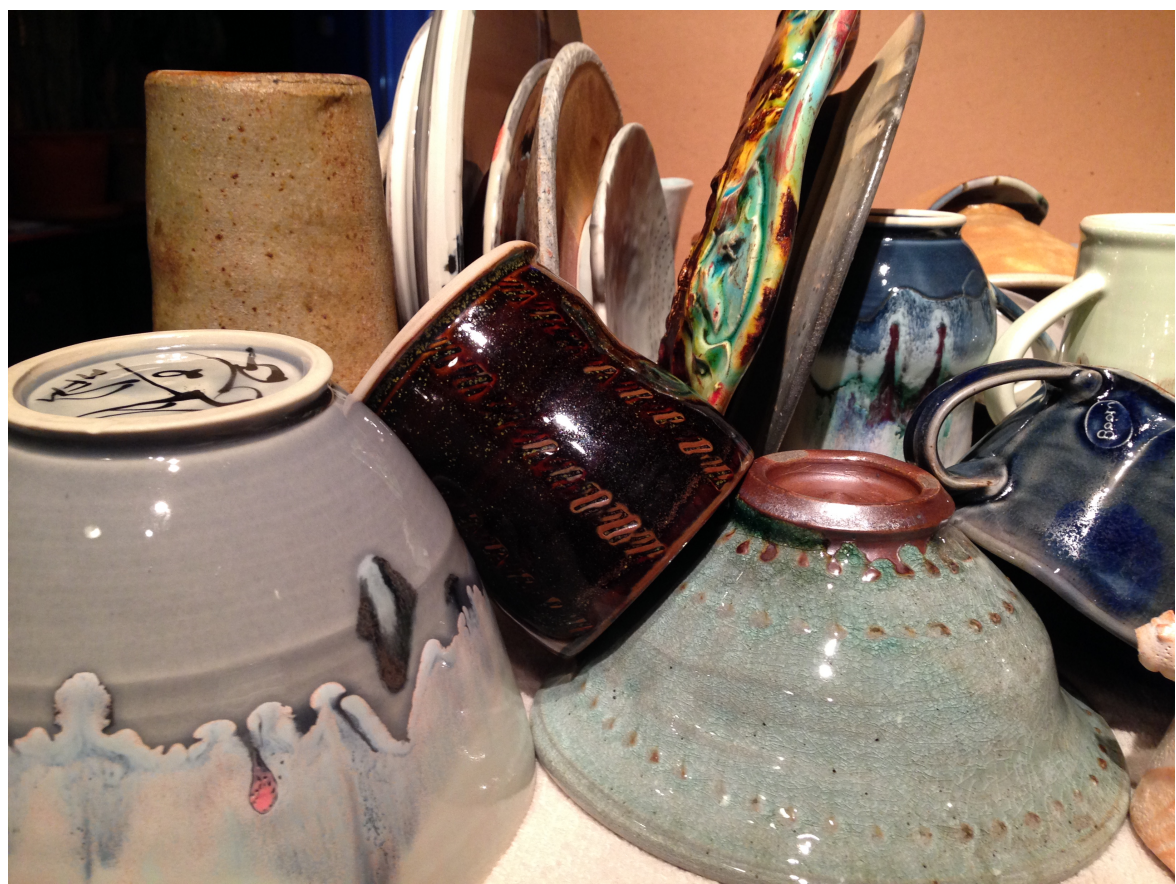

Fig. 1. Andrew Kellner, Stacked Dishes, 2017 (Photo courtesy of Victoria Kellner)
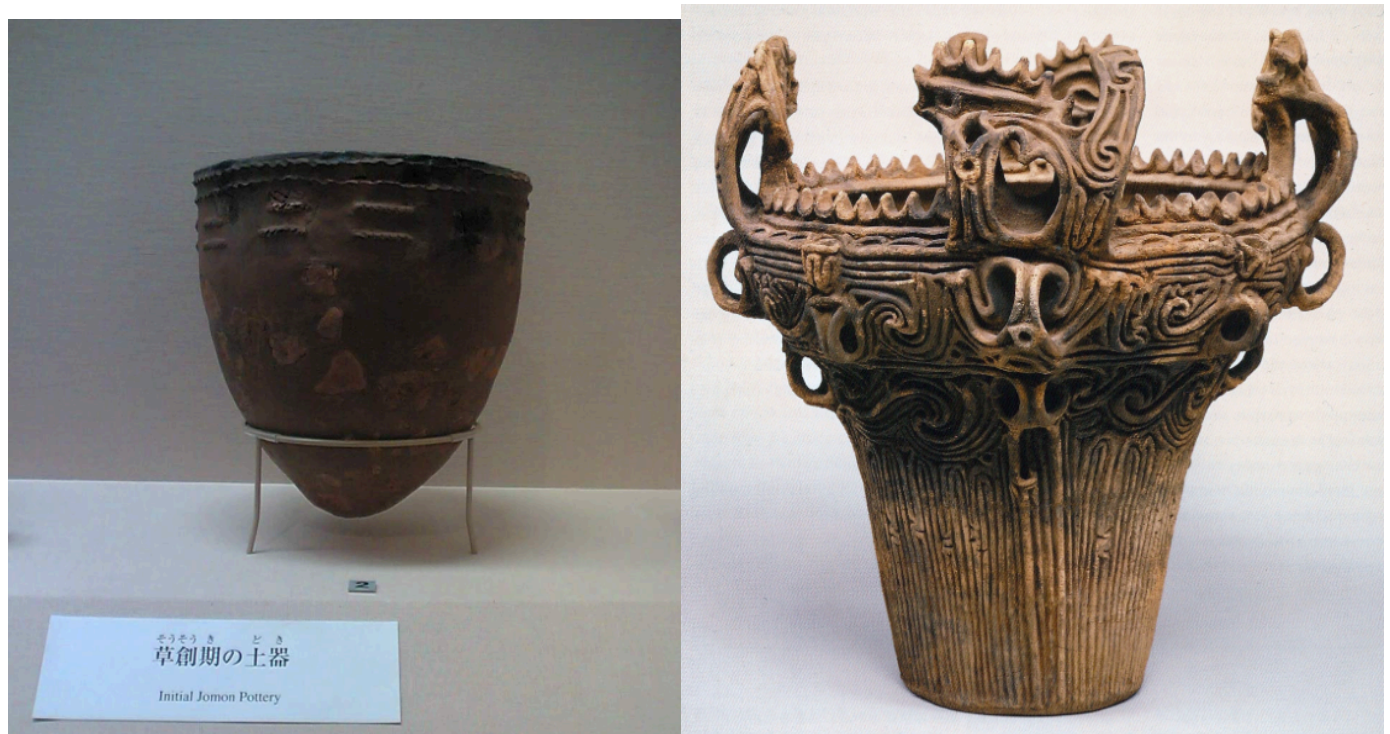

Fig.2. Incipient Jōmon, Japan (Left) (14,000-8,000 B.C.E), Tokyo National Museum https://heritageofjapan.files.wordpress.com/2008/08/initial-jomon-pottery.jpg (Date accessed 04/1/2017)

Middle Jōmon, Japan (Right) (2500 - 1500 B.C.E) Ospina, Ignacio . "Jomon Period | Prehistoric Japanese Pottery." Jomon Period | Prehistoric Japanese Pottery. Accessed April 01, 2017. http://emerald.tufts.edu/programs/mma/fah188/ospina/jomon/. 


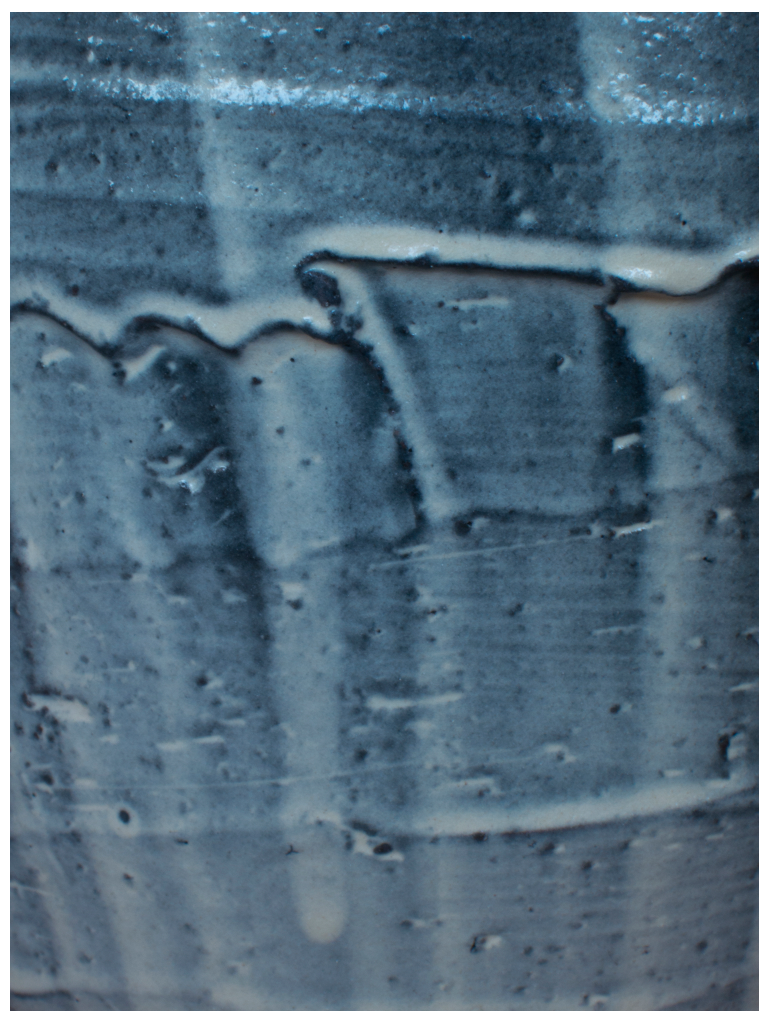

Fig. 3. Andrew Kellner, Jug (detail), 2017, $\Delta 3$ Salt-fired earthenware (photo by artist)

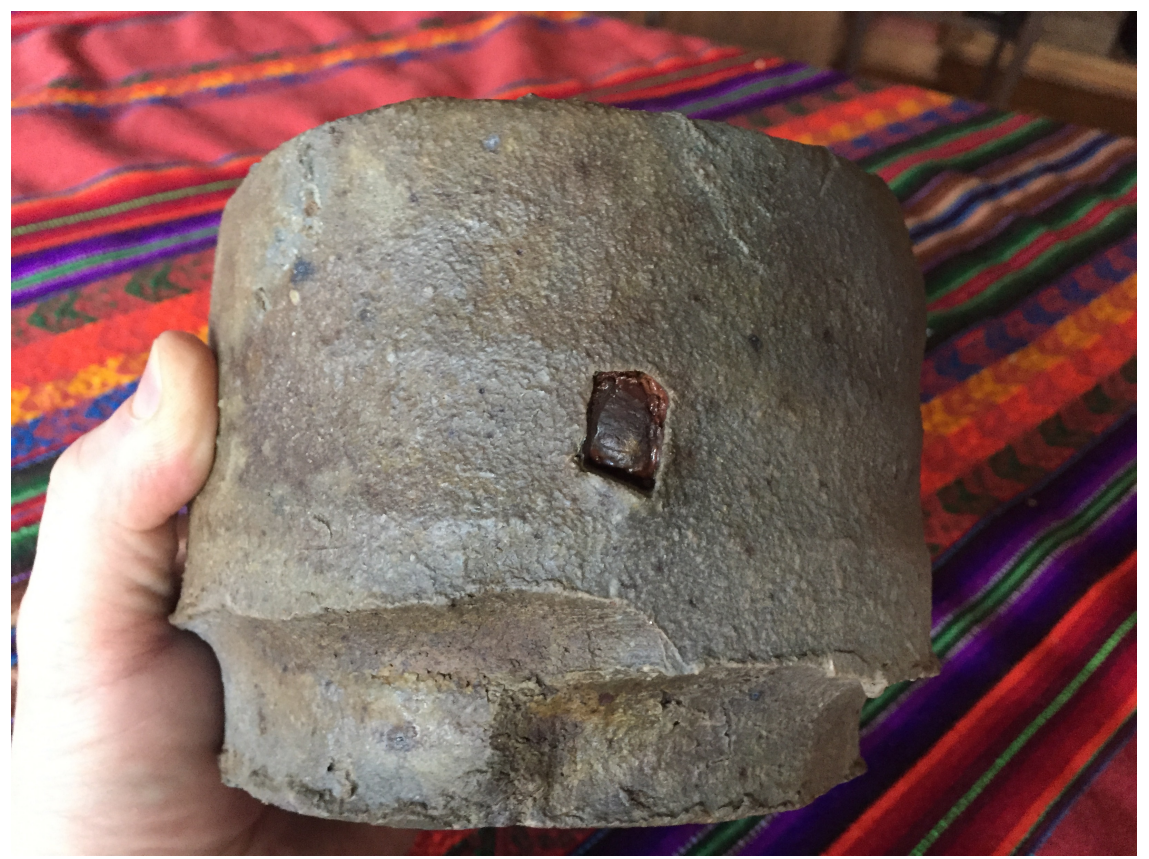

Fig. 4 Peter Voulkos, Tea Bowl (detail), n.d, Woodfired Stoneware, (Collection of Ron and Hester Myers) 


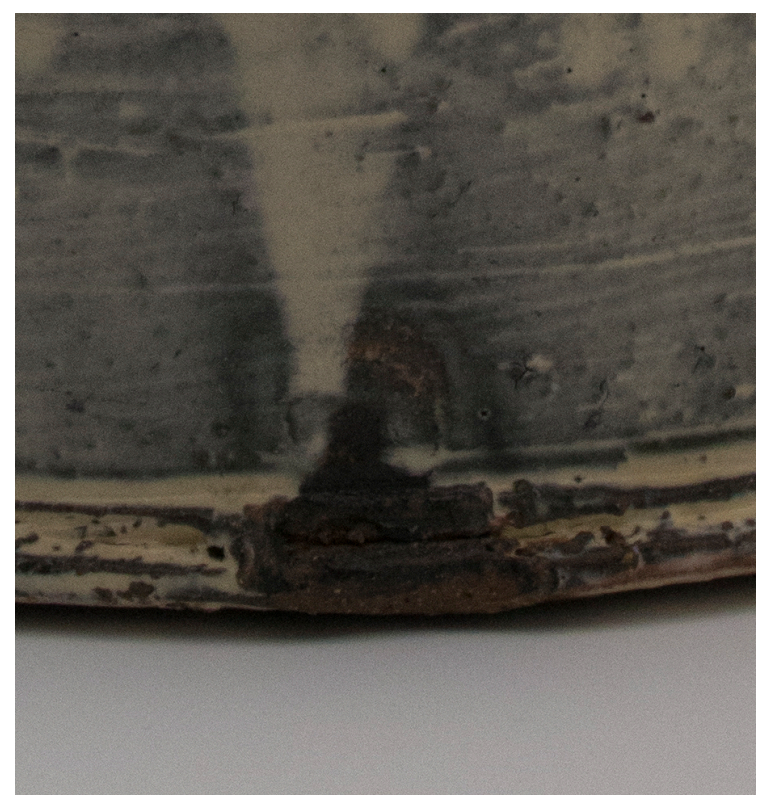

Fig. 5. Andrew Kellner, Flower Brick (detail), 2017, $\Delta 3$ Salt-fired earthenware (photo by artist)

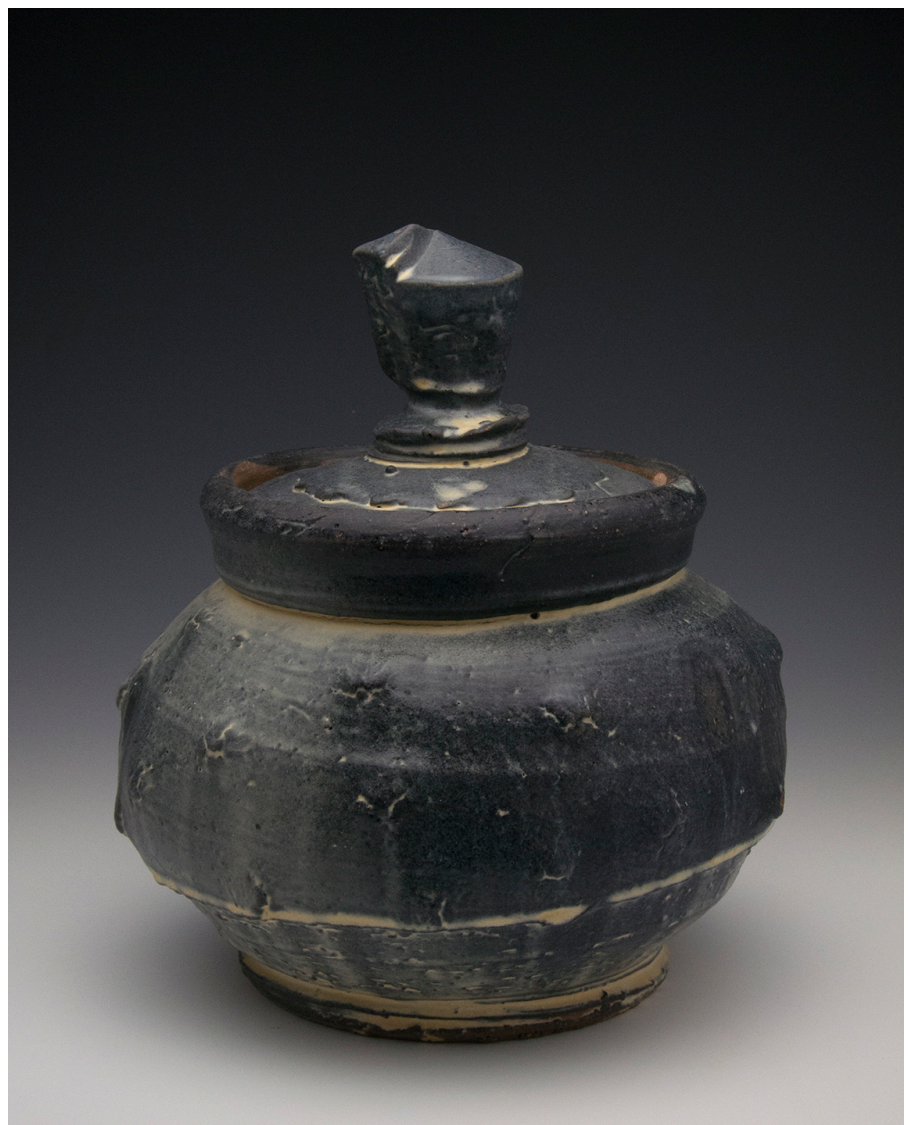

Fig. 6. Andrew Kellner, Small Jar, 2017, $\Delta 3$ Salt-fired earthenware (photo by artist) 


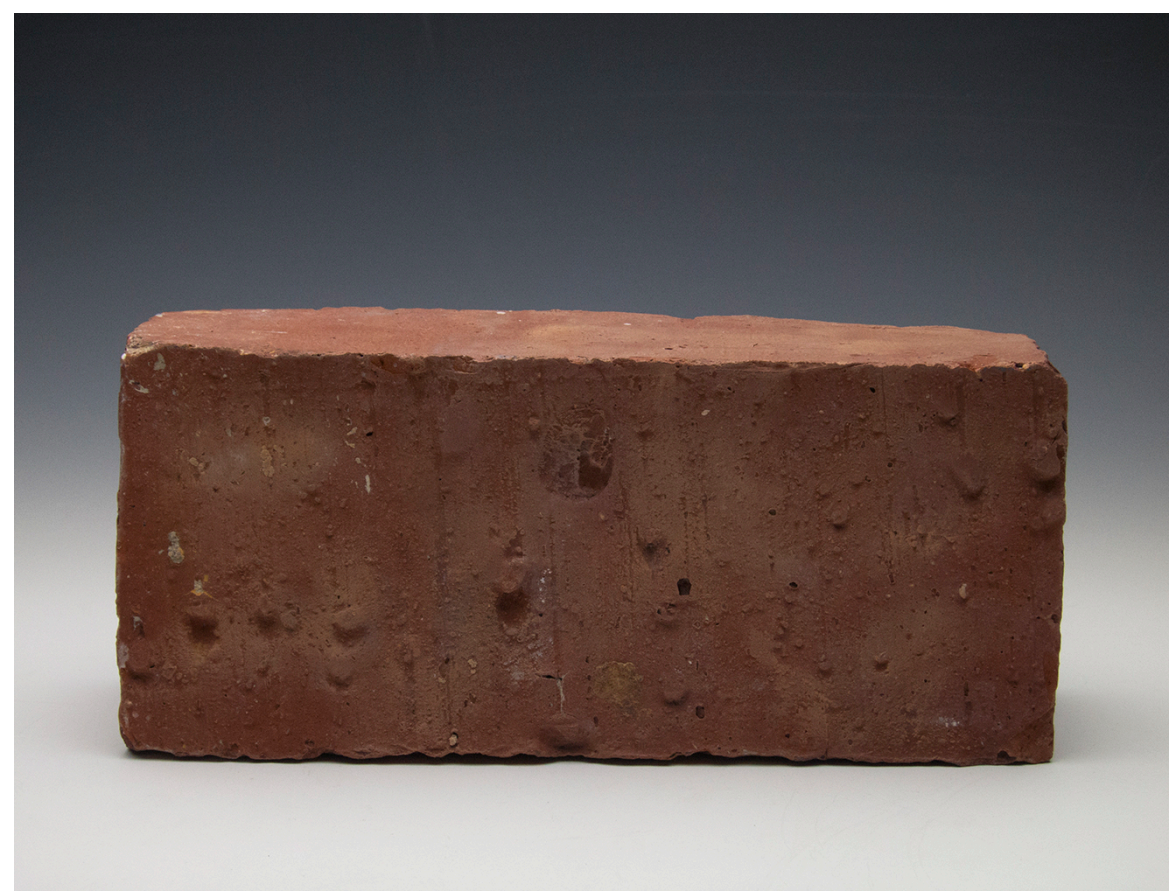

Fig.7. Watershed Brick Factory, Wet Struck Brick, n.d, (Photo by artist)

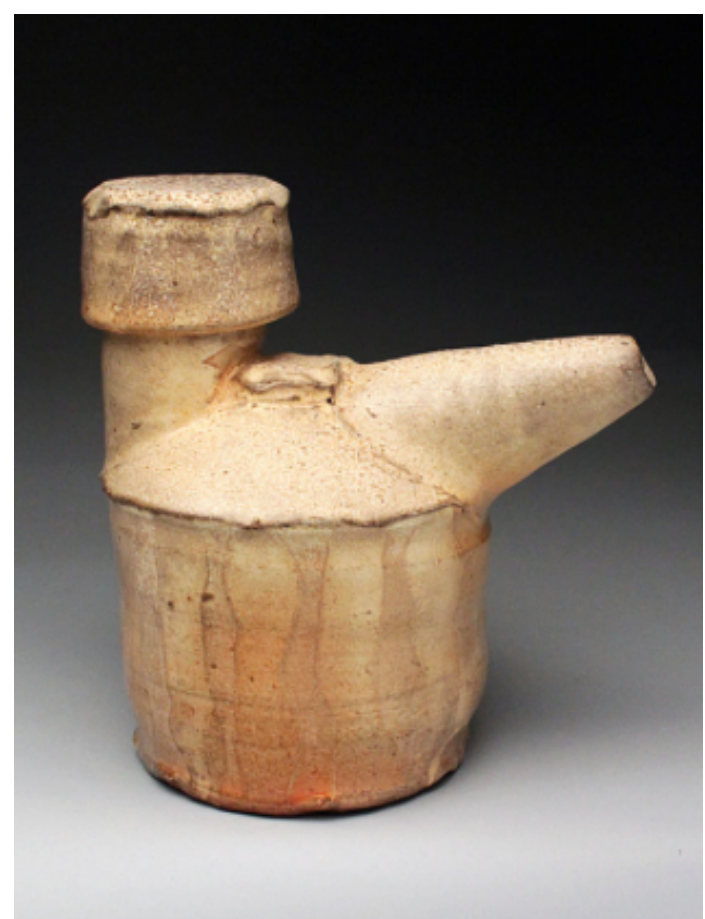

Figure. 8. Linda Christianson, Cooking Oil Can, 2017, Wood/Salt fired Stoneware (http://www.mudfire.com/linda_christianson/linda_christianson_lch08_/ (Date accessed 03/5/2017) 


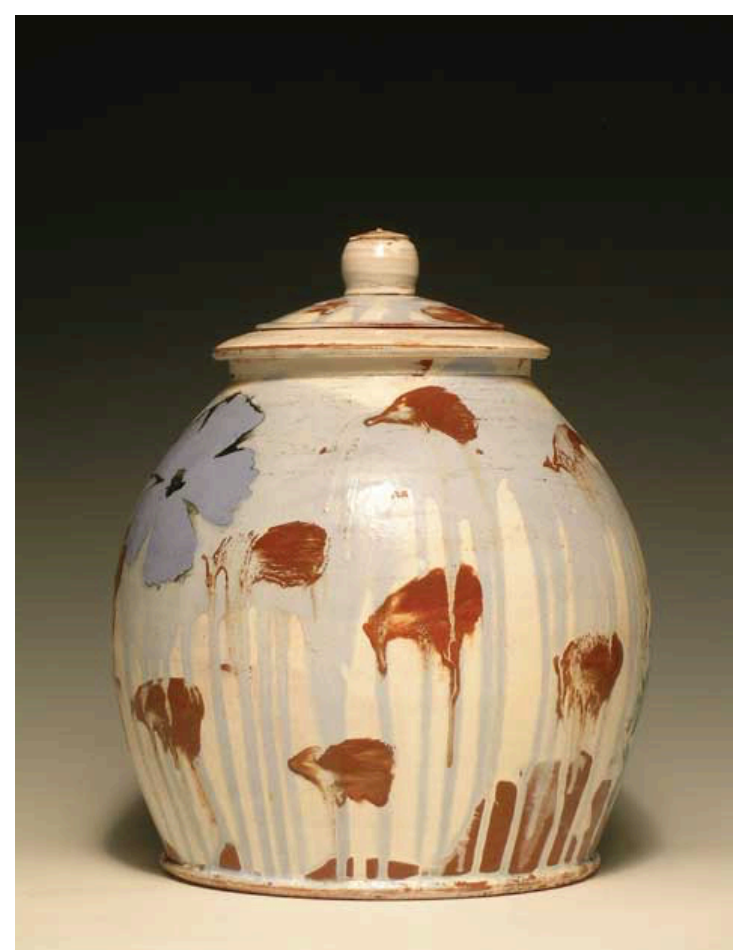

Fig. 9. Steven Colby, Lidded Jar, 2011, Earthenware http://ceramicartsdaily.org/daily/staff-picks-top-three-ceramics-exhibitions-andevents-march-2011/ (Date accessed 03/5/2017)

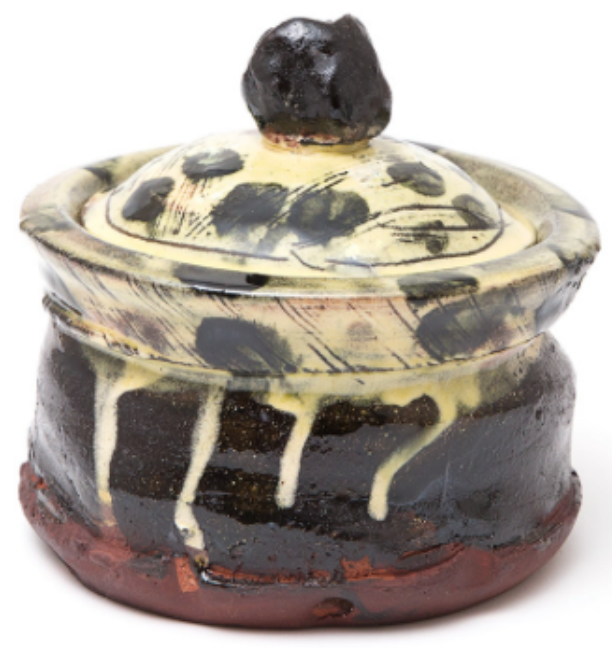

Fig. 10. Jean Nichols-Gerrad, Small Lidded Jar, 2016, Earthenware https://www.goldmarkart.com/index.php? option=com_virtuemart\&view=produc tdetails\&virtuemart_product_id=15848\&virtuemart_category_id=235\&ltemid=442 (Date accessed 03/5/2017) 


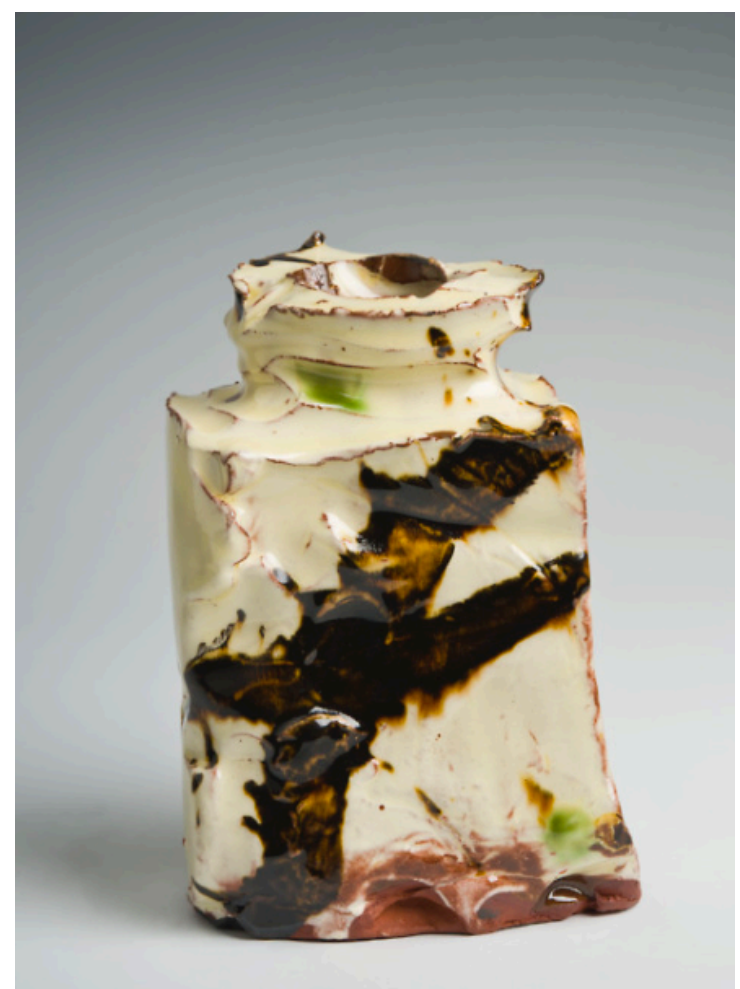

Fig. 11. Dylan Bowen, Soft Cut Form, n.d, Earthenware http://www.dylanbowen.co.uk/gallery (Date accessed 03/5/2017)

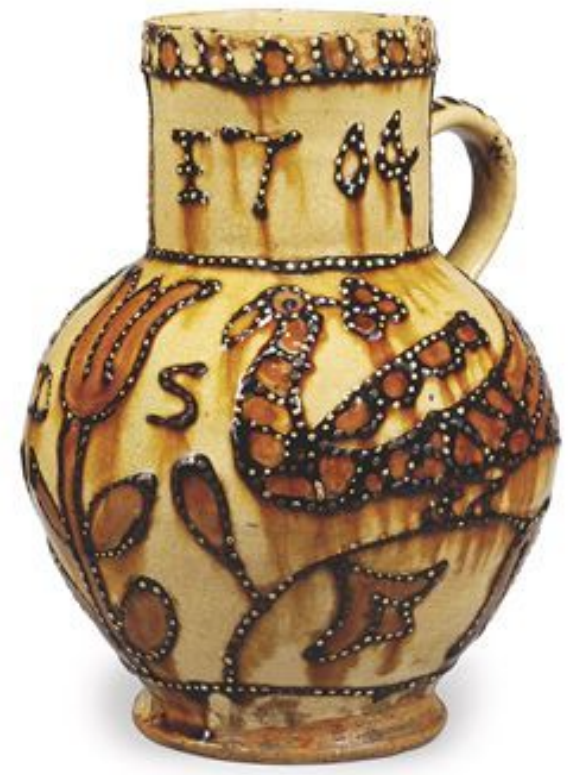

Fig. 12. Staffordshire Slipware Jug, 1704, Earthwnware http://collections.vam.ac.uk/search/? category\%5B0\%5D=166\&offset=0\&place\% $5 \mathrm{~B} \% 5 \mathrm{D}=\times 29181$ \&narrow $=1$ (Date accessed 03/5/2017) 


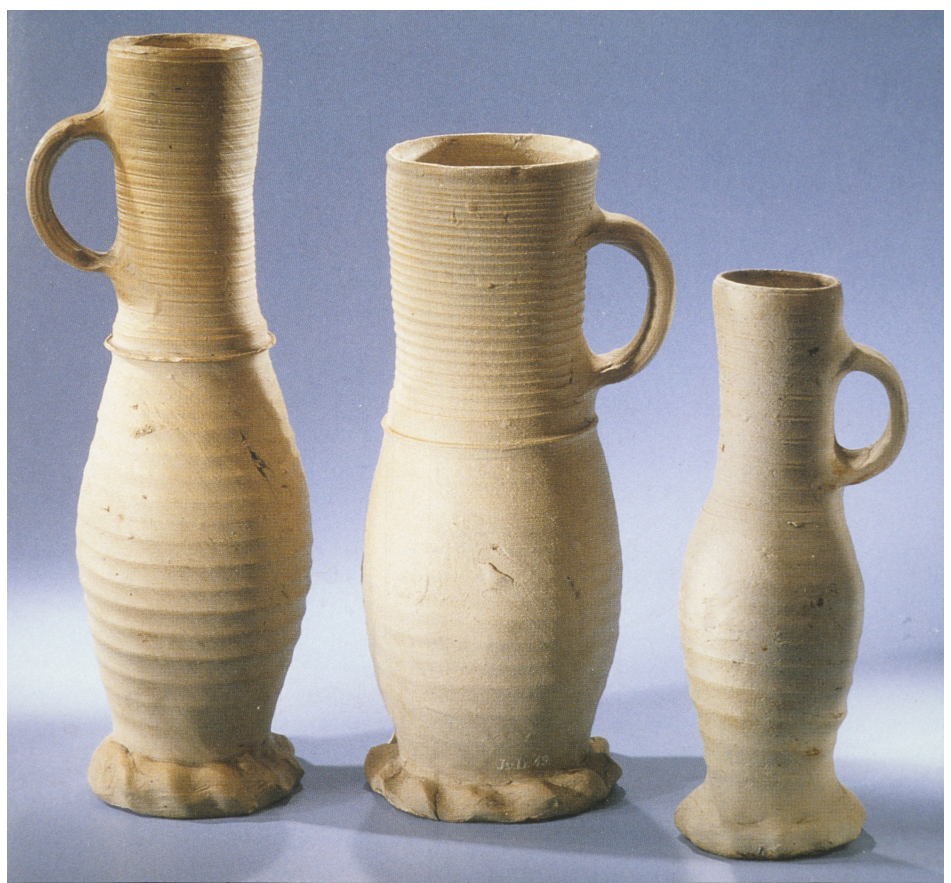

Fig. 13. Siegburg Pottery, Jacoba Jugs, $14^{\text {th }} / 15^{\text {th }} \mathrm{C}$.

Jacoba Jugs. N.d. Rijksmuseum, Amsterdam. Duits steengoed - German stoneware. Amsterdam: Waanders, 1996. N. pag. Print.

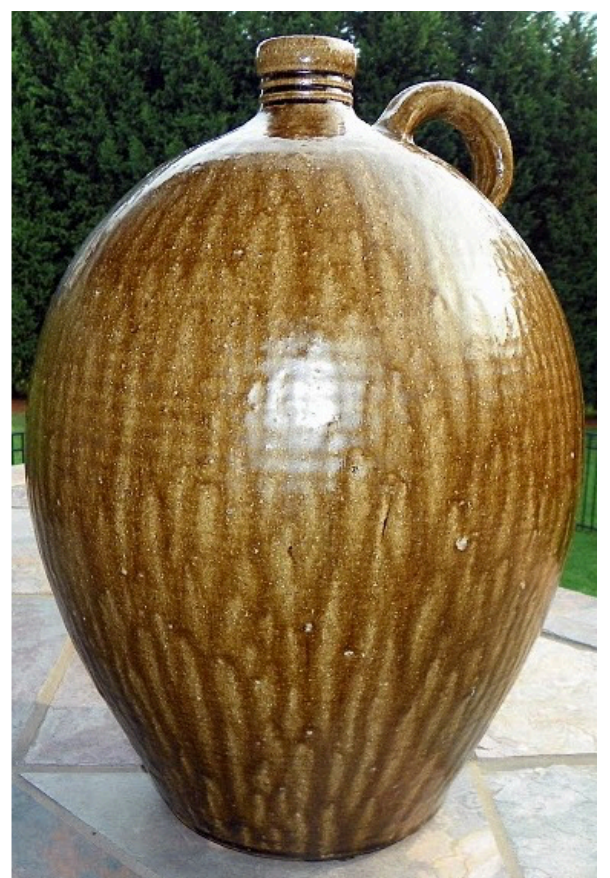

Fig. 14. Daniel Seagle, 4 Gallon Jug, Seagrove North Carolina, 1805-67, Stoneware.

" A 70-Year Tradition of Pottery Making in the Catawba Valley." www.DanielSeagle.com - Home. 2008. (Date Accessed April 01, 2017) http://danielseagle.com/home. 


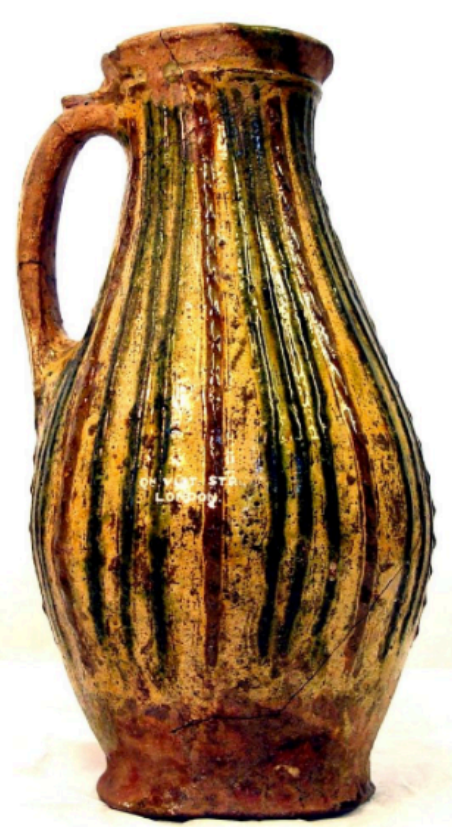

Fig. 15. Baluster Jug, England, 14th c. Earthenware

http://www.britishmuseum.org/research/collection_online/collection_object_det ails.aspx? assetld=342883001 \&objectld $=14254 \&$ partld $=1$ (Date Accessed April 1st, 2017

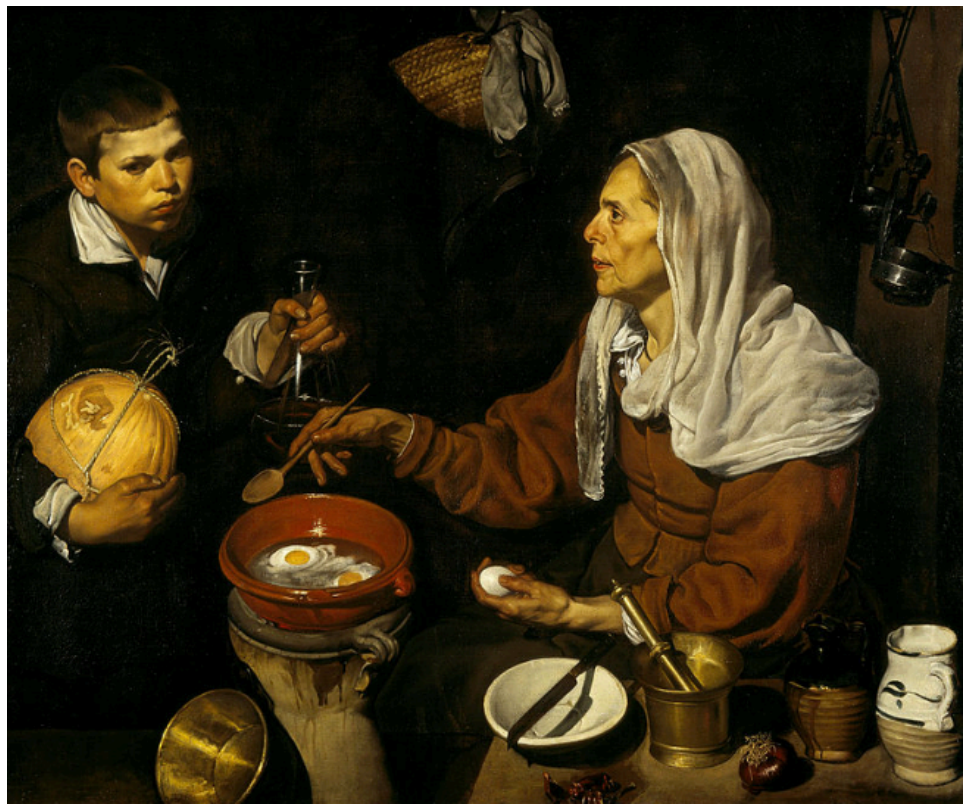

Fig.16. Diego Velázquez, Old Women Frying Eggs, 1618 http://www.artble.com/artists/diego_velazquez/paintings/an_old_woman_cooki ng_eggs (Date Accessed April 1st, 2017) 


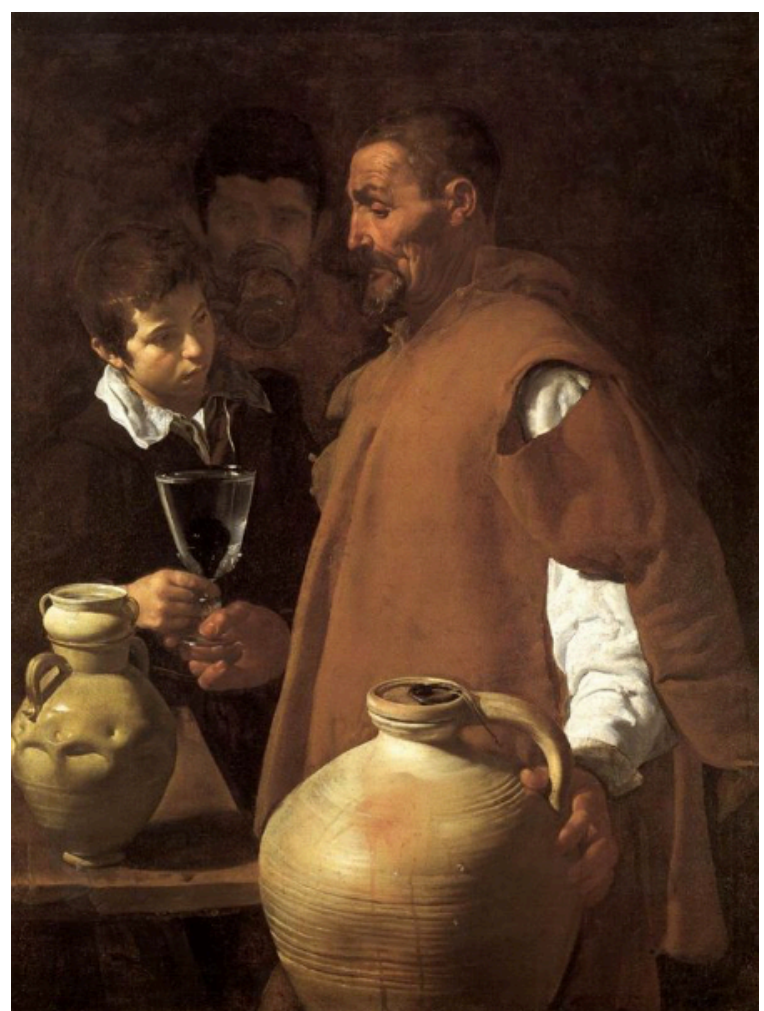

Fig. 17. Diego Velazquez, Waterseller of Seville, 1618-1622 http://www.artble.com/artists/diego_velazquez/paintings/the_waterseller_of_sev ille. (Date Accessed April 1st, 2017)

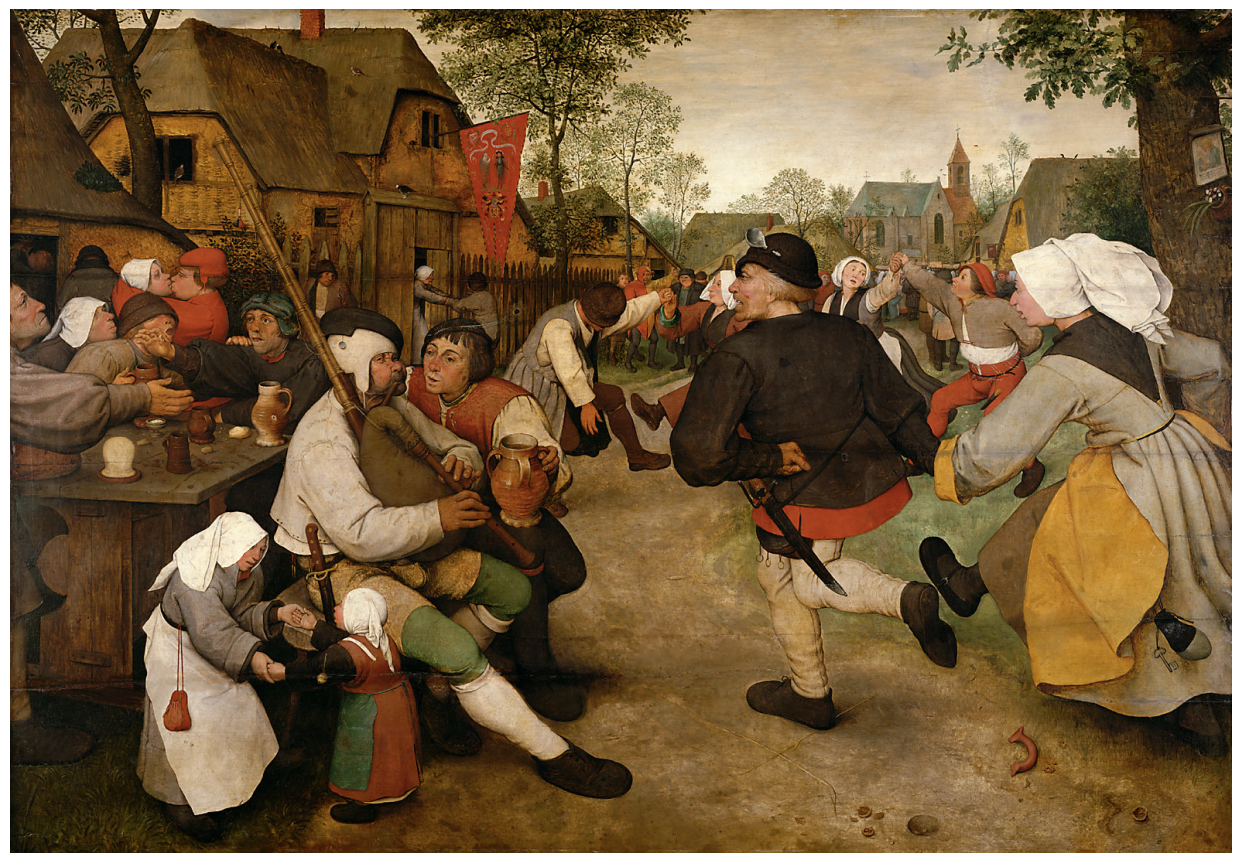

Fig. 18. Pieter Bruegel the Elder, The Peasant Dance, 1567

https://www.khm.at/objektdb/detail/331/?offset=6\&lv=list\&cHash=a335153971 bf 1490c3a7ac2a4adbald4 (Date Accessed April 1 15, 2017) 

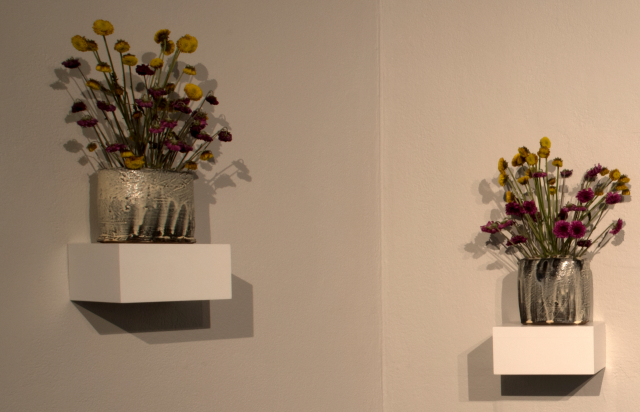

\section{HIGH TOUCH}

\section{ANDREW KELINER}

Fig.19. Andrew Kellner, High Touch (Exhibition Title), 2017. (Photo by Michael Oliver)

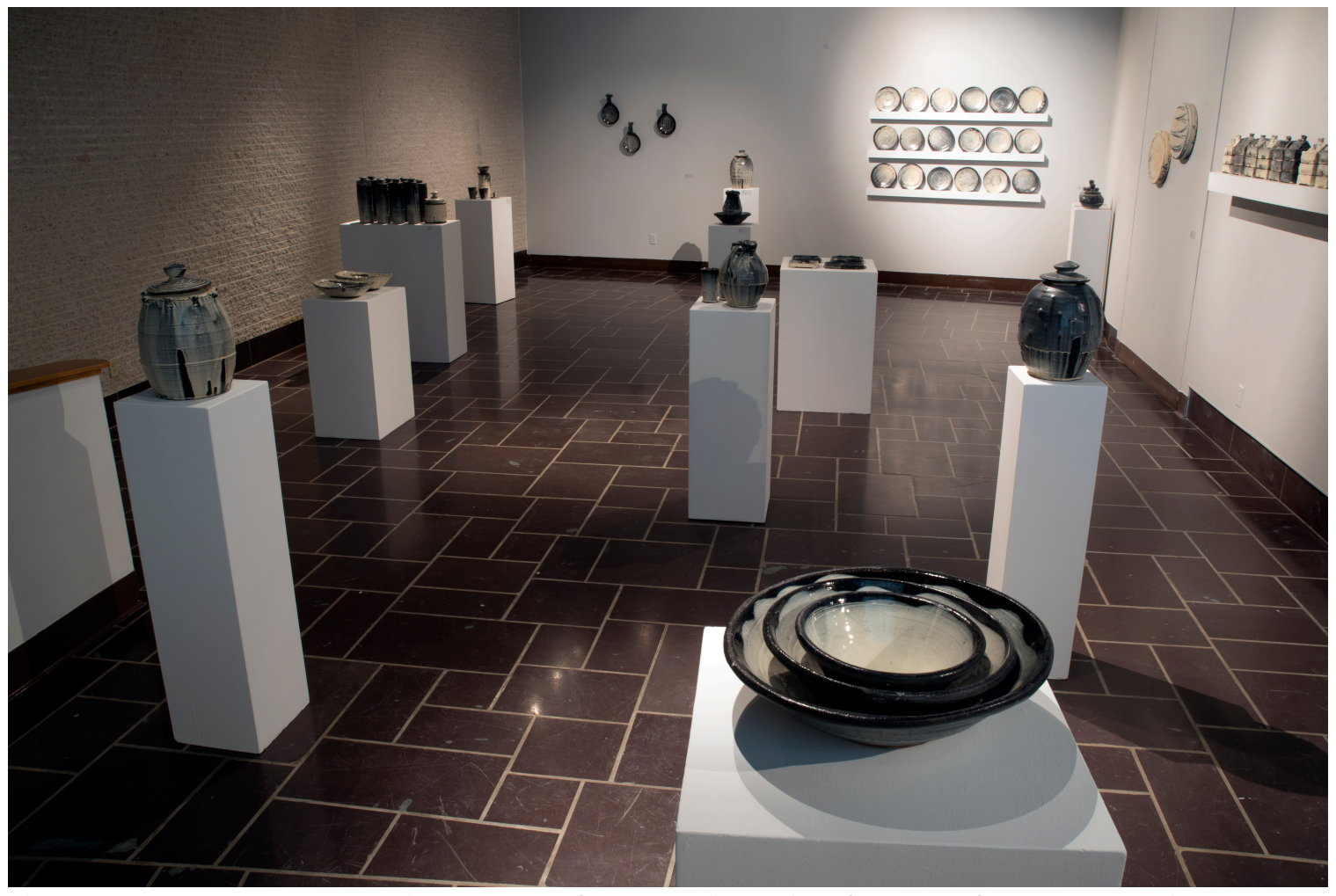

Fig.20. Andrew Kellner, High Touch (Installation View), 2017. (Photo by Michael Oliver) 


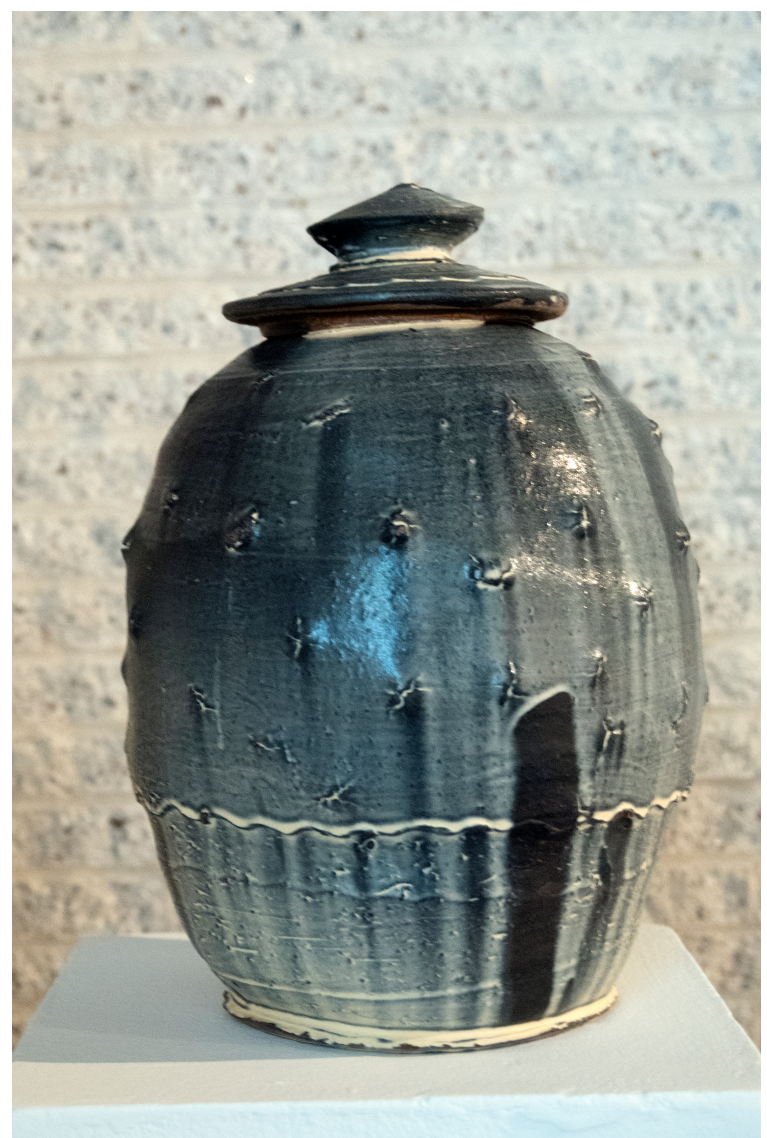

Fig.20. Andrew Kellner, Storage Jar, 2017, $\Delta 3$ Salt-fired earthenware (Photo by Michael Oliver)

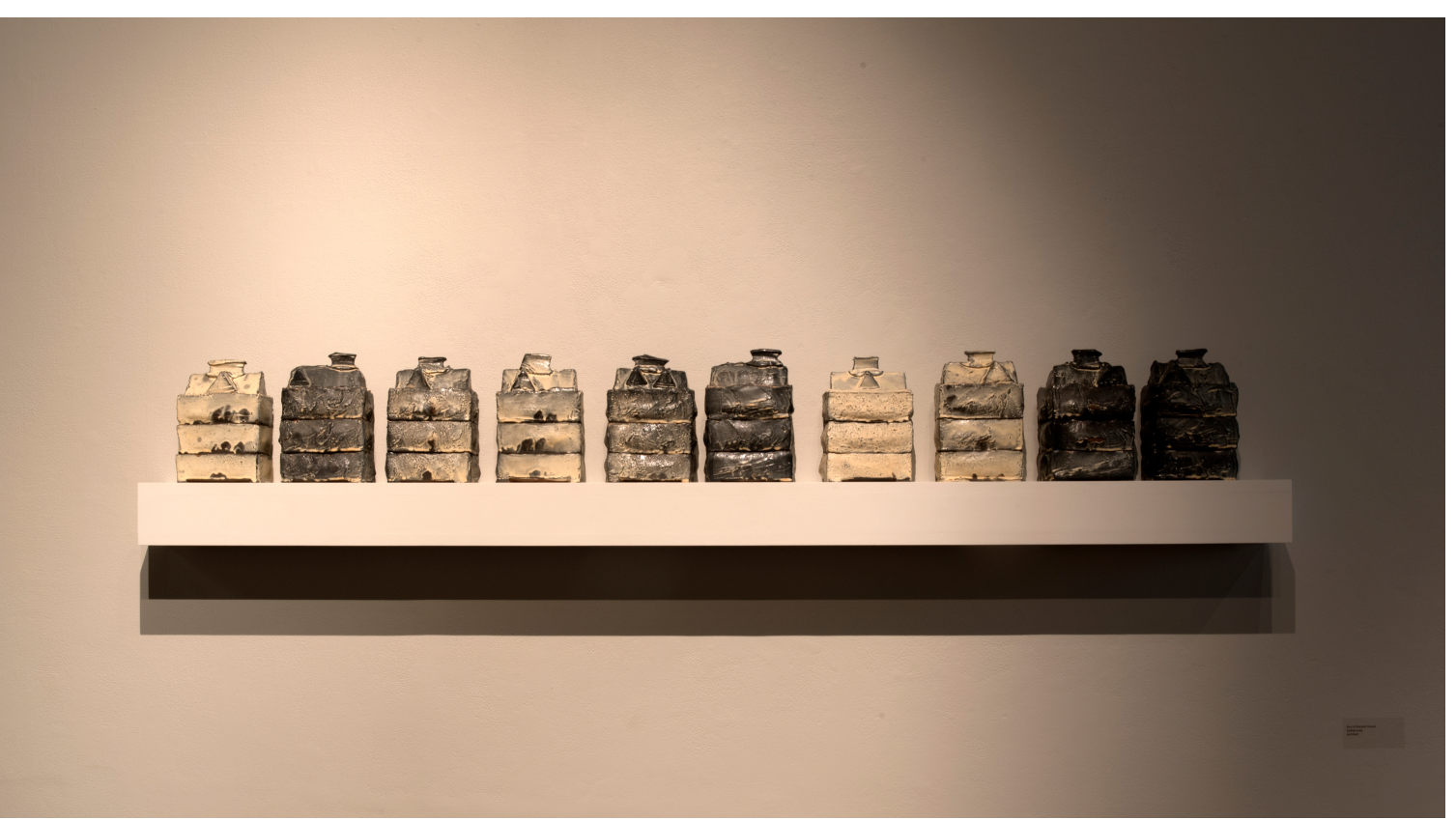

Fig.21. Andrew Kellner, Stacked Houses, 2017, $\Delta 3$ Salt-fired earthenware (Photo by Michael Oliver) 


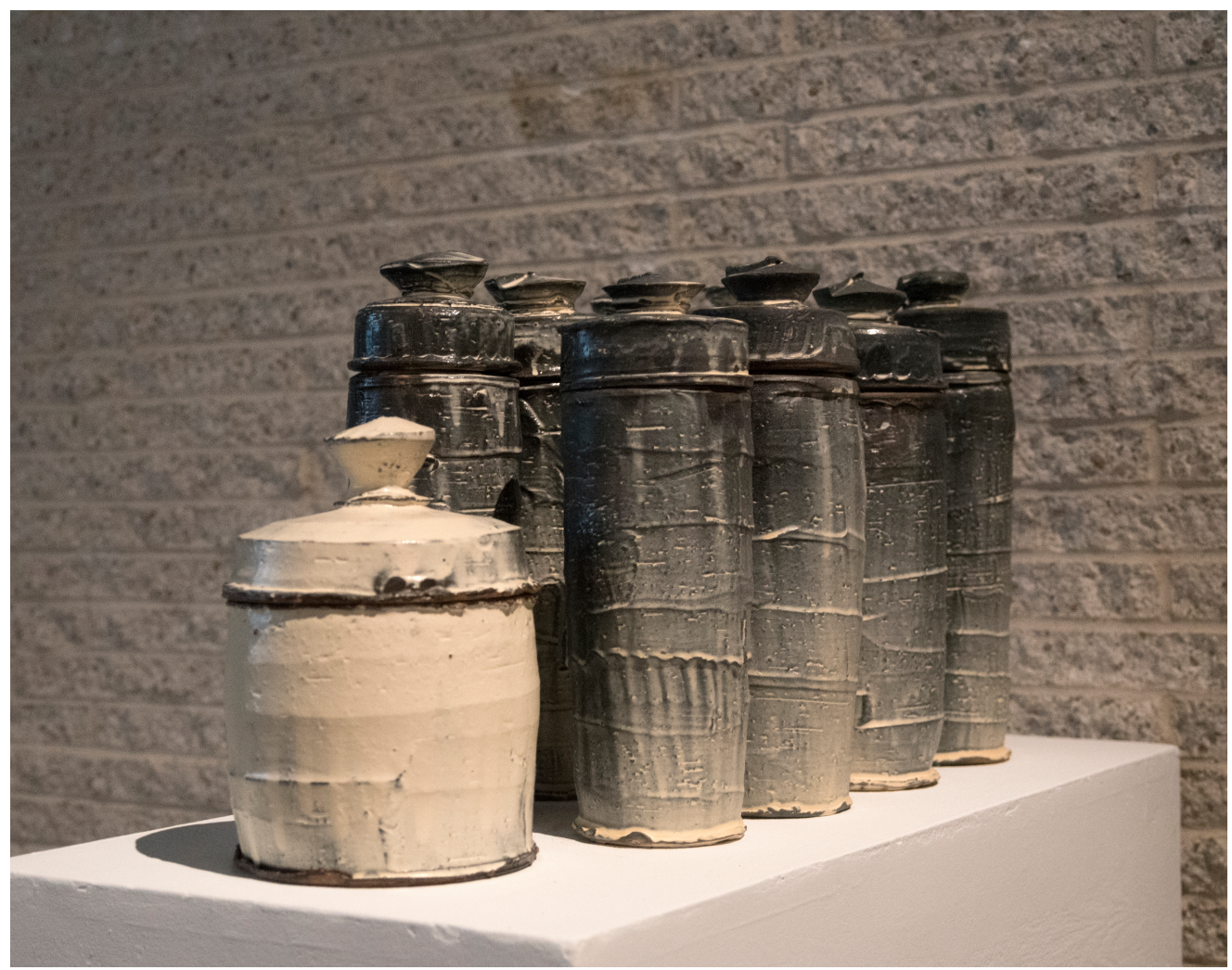

Fig.22. Andrew Kellner, Canisters Jars, 2017, $\Delta 3$ Salt-fired earthenware (Photo by Michael Oliver)

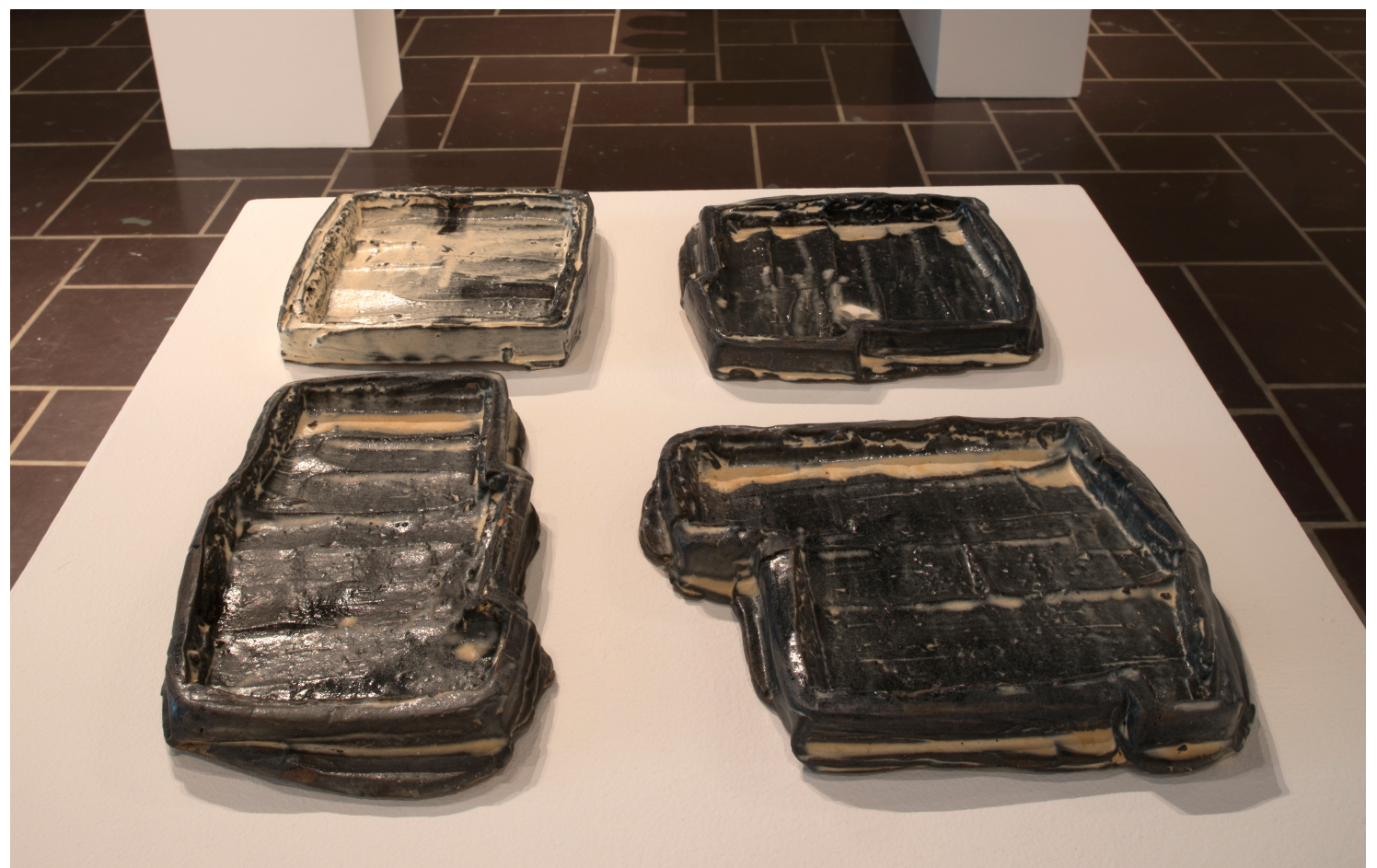

Fig.23. Andrew Kellner, Variations of PB\&J Plates, 2017, $\Delta 3$ Salt-fired earthenware (Photo by Michael Oliver) 


\section{Bibliography}

Adamson, Glenn. Thinking through Craft. Oxford: Berg, 2007. Print.

Beckley, Bill, and David Shapiro, eds. Uncontrollable Beauty: Toward a New Aesthetics. New York: Allworth :, 1998. Print.

Bryson, Norman. Looking at the Overlooked: Four Essays on Still Life Painting. London: Reaktion, 1990. Print.

Camus, Albert. The fall. Trans. Justin O'Brien. New York: Vintage, 1991. Print.

Camus, Albert. The myth of Sisyphus and other essays. Trans. Justin O'Brien. New York: Vintage, 1991. Print.

Camus, Albert. The stranger. Trans. Matthew Ward. New York: Vintage International, 1989. Print.

Capistrano-Baker, Florina H., Albert S. Bacdayan, B. Lynne Milgram, and Roy W. Hamilton. Basketry of the Luzon Cordillera, Philippines. Los Angeles: UCLA Fowler Museum of Cultural History, 1998. Print

Cardew, Michael. Pioneer Pottery. Westerville: American Ceramic Society, 2002. Print.

Carter, Ben. Audio blog post. Tales of a Red Clay Rambler. Blogger, n.d. Web.

Fariello, M. Anna., and Paula Owen. Objects and Meaning: New Perspectives on Art and Craft. Lanham, MD: Scarecrow Press, 2004. Print.

Fried, Andrew, David Gelb, Brian McGinn, and Matt Weaver, prods. Chef's Table. Netflix. 2015.

Gillies, Carter. Web log post. Carter Gillies Pottery. Wordpress, n.d. Web.

Hewitt, Mark, and Nancy Sweezy. The Potter's Eye: Art and Tradition in North Carolina Pottery. Chapel Hill: Published for the North Carolina Museum of Art by the University of North Carolina Press, 2005. Print.

Hickey, Dave. The Invisible Dragon: Essays on Beauty. Rev. and Expanded ed. Chicago: U of Chicago, 2009. Print.

"Jomon cuisine: What went into the Jomon pots?" Heritage of Japan. January 28, 2014. Accessed April 01, 2017. https://heritageofjapan.wordpress.com/just-whatwas-so-amazing-about-jomon-japan/ways-of-the-jomon-world-2/jomon-craftsand-what-they-were-for/ways-of-the-jomon-world/jomon-cuisine-what-went-intothe-jomon-pots/. Web. 
Kuroda, Ryo, and Takeshi Murayama. Classic Stoneware of Japan: Shino and Oribe. Combined ed. Tokyo: Kōdansha International, 2002. Print.

Leach, Bernard. A Potter's Book. [2nd ed. London: Faber and Faber, 1945. Print.

Mathieu, Paul. The Art of the Future: 14 Essays of Ceramics. 2008

www.paulmathieu.ca/. Web.

McGarva, Andrew. Country Pottery: The Traditional Earthenware of Britain.

London: A. \& C. Black, 2000. Print.

Metcalf, Bruce. "Looking Back, Looking Forward." Address, The Annual

Convention of The National Council on Education for the Ceramic Arts, Louisville, Kentucky, 2007.

Metcalf, Bruce. "The Hand: At the Heart of Craft." American Craft 60, no. 4 (August/September 2000).

Needleman, Carla. The Work of Craft: An Inquiry into the Nature of Crafts and Craftsmanship. New York: Knopf, 1993. Print.

Oka, Hideyuki. How to Wrap Five Eggs: Traditional Japanese Packaging. Boston: Weatherhill, 2008. Print.

Pinnell, Pete. "Transcending the Naked Truth." Clay Times, May 1, 2004, 19-21.

Pye, David. The Nature and Art of Workmanship: David Pye,... London: Herbert, 1995. Print.

Pye, David. The Nature and Aesthetics of Design. London: Herbert, 2007. Print.

Rawson, Philip S. Ceramics. Philadelphia: U of Pennsylvania, 1984. Print.

Risatti, Howard. A Theory of Craft: Function and Aesthetic Expression. Chapel Hill: U of North Carolina, 2007. Print.

Rhodes, Daniel. Tampa Pottery The Timeless Art of a Japanese Village. Tokyo: Kondasha International, 1970. Print.

Rogers, Bill. "Brian Rochefort: High Mass Goblets for Glaze Worship." CFile Contemporary Ceramic Art Design. October 12, 2014. Accessed September 03, 2016. https://cfileonline.org/. Web.

Staley, Chris. The Challenge of Making Pots at a University. Ceramics Monthly, February 1, 1996.

Trilling, James. The Language of Ornament. New York: Thames \& Hudson, 2001. Print. 
Wood, Karen Ann. Tableware in Clay from Studio and Workshop. Wiltshire, Eng.: Crowood Press, 1999. Print.

Yanagi, Sōetsu, and Bernard Leach. The Unknown Craftsman; a Japanese Insight into Beauty. New York: Kodansha USA, 2013. Print. 
Education and Personal Development

2015 - P MFA Candidate 2017, West Virginia University, Morgantown, WV

2014 The Pottery Work Shop, Jingdezhen, China

Three-month Study abroad program with WVU

2010-2012 Ontario College of Art and Design University, Toronto, ON

Textile Design

2005 Alberta College of Art and Design BFA in Ceramics, Calgary, AB

Apprenticeship under Martin Tagseth, Lake Lenore, Sask, Canada

Apprenticeship

2004 Australian National University, Canberra Australia

Six-month Study abroad with ACAD

2003 Sheridan College of Craft and Design, Oakville, ON

Ceramics Diploma

2002 Summer Assistant at Donn Szver Pottery, Troy ON

Work Experience

2016

Summer studio staff, Watershed Centre For the Ceramic Arts

$2015-P$

Graduate Teaching Assistant, School of Art of Design, West Virginia University, Morgantown WV.

Courses Taught: Intro to Hand-building. (Instructor of Record)

Intro to Wheel-Throwing. (Instructor of Record)

Ceramics for Non-Majors. (Instructor of Record)

Foundations 2D Design. (Instructor of Record)

2010-2014 Lead Ceramics Technician, Burlington Art Centre, Burlington, ON

Ceramics Instructor, Burlington Art Centre, Burlington, ON

- Instructing adults and children in beginner, to advanced ceramics

2009

Ceramics Instructor, Gardiner Museum, Toronto, ON

ceramics

- Instructing intermediate handbuilding and wheel throwing

$2008-2011 \quad$ Studio Potter, Toronto, ON 


\section{Related Experience}

Assisted construction in 120 cubic foot anagama wood kiln, L. Lenore, Sask. Assisted construction in 80 cubic foot car kiln, $A C A D A B$

Solely constructed 60 cubic foot burry box wood kiln, Australian National University, Canberra

Assisted construction in 60 cubic foot salt/soda kiln, Oakville, Sheridan College, ON

\section{Exhibitions}

High Touch, MFA Thesis Show, Mesaros Gallery, Morgantown, WV [solo]

Beyond The Brick Yard, Archie Bray, Helena, MT, [juried]

NCECA: National Student Juried Exhibition, The Hoffman Gallery, Portland, OR [juried]

The O'I College Try, Artists Image Resource Pittsburgh, PA

2016

NCECA: National Student Juried Exhibition, Leedy-Voulkos Art Center, Kansas City, KS [juried]

Tabletop Show, Art League Gallery, Alexandria, VA [juried]

Twin Cups: National Ceramics Exhibition, MWSU Clay Guild, St Joseph, MO [juried]

The Cup The Mug Exhibition, Main street Arts, Clifton Springs, NY [juried]

Confluence, Artists Image Resource Pittsburgh, PA

Surroundings: MFA Student Show, Mesaros Gallery, Morgantown, WV

Function, Diamond Shop, Morgantown, WV.

2015 Tabletop Show, Art League Gallery, Alexandria, VA [juried]

Confluence, Artists Image Resource Pittsburgh, PA

2014 Made in China, Mufei Gallery, The Pottery Workshop Jingdezhen, CH

Awards

2016

Studio Potter Graduate Merit Award, NCECA: National Student Juried Exhibition Jurors Choice Award, The Cup The Mug Exhibition 